SVU- International Journal of Veterinary Sciences, 1 (1): 90 - 101, 2018.

Print ISSN: 2535-1826

Online ISSN: 2535-1877

Research Article

Open Access

\title{
Potential Regenerative Capacity of physiological serum, L-arginine and IGF-1 on Skeletal Muscle
}

\author{
Naglaa M. Alkalamawy \\ Animal Health Research Institute, Pathology Department, Dokki, Giza
}

Abstract

In post-mitotic tissues such as skeletal muscles there are no significant cell replacements throughout life; the cells sustain local damage through its pool of specified stem cells. Muscle satellite cells are mononuclear cells that remain in a quiescent state till be activated; when they proliferate and fuse with muscle fibers to donate myonuclei, a process necessary for postembryonic growth, hypertrophy and tissue repair in this post-mitotic tissue. Modern trends in using (autologous) biological agents in initiation of regenerative process encourage us to evaluate the efficacy of some of these agents. In this study muscle damage was induced by cardiotoxin; followed by administration of biological agents; autologous physiological serum, L-arginine and IGF-1 as a stimulating factors of myogenic satellite cells to initiate the myogenic regenerative process.

Our study refers to variable degrees of efficacy in stimulation of myogenic stem cells differentiation and the outcome of the regenerative process. Although the physiological serum had marked ability to stimulate MSC but high number of newly formed myotubules are split. L-arginine despite had delayed regenerating time, but more organization of newly formed myotubules was retained. IGF-1 had rapid effect but associated with considerable number of newly formed split myotubules. We could conclude that for perfect regenerative myogenic tissue not main just formation muscle fibers, but theses fibers must be organized and functional. Healthy functional regenerative process need synchronization of several agents should be considered.

Keywords: Myogenic stem cell, IGF-1, Serum, L-arginine, Skeletal muscle regeneration, Cardiotoxin.

Received: June 1, 2018

Accepted: June 15, 2018

Published: June 30, 2018

Corresponding Author: Naglaa M. Alkalamawy $\quad$ E-mail: n.alkalamawy@yahoo.com

Citation: Alkalamawy, 2018. Potential Regenerative Capacity of physiological serum, L-arginine and IGF-1 on Skeletal Muscle. SVU-IJVS, 1 (1): 90 - 101.

Copyright: This is an open access article distributed under the terms of the creative common attribution license, which permits unrestricted use, distribution and reproduction in any medium provided the original author and source are created.

Competing interest: The authors have declared that no competing interest exists. 


\section{Introduction}

Skeletal muscles are highly dynamic tissue so there are continuous cycles of degeneration and regeneration mediated by its content of resident stem cells (myogenic satellite cells) and directed by specific agents known as myokines (Chang and Rudnicki, 2014). Some of these myokines are secreted form the skeletal muscle which is known to play an endocrine role in the regenerative process (Pedersen and Febbraio, 2012); these myokines and other specific growth factors have either positive or negative effect on the myogenic process (Pal et al., 2014). Locally produced growth factors had an important role in the removal of necrotic materials in skeletal muscle after hazardous insult as well as its role in muscle fibers repair (Adams, 2002).

A successive regenerative process was established to be mediated by inflammatory cell infiltrations (mainly neutrophils followed by macrophage and lymphocytes), that begin $2 \mathrm{hrs}$ post injury and aimed for removal of necrotic fibers in addition to the enhancement effect of macrophage on myogenic satellite cell through production of inducible NO synthase (Rigamonti et al., 2013); followed by activation, differentiation and fusion of satellite cells (new myoblast), and finally maturation and remodeling of the newly formed myoblasts with existing myofibers (Yin et al., 2013).

This study aimed to investigate in a comparative manner the effectiveness of some biological; autologous physiological serum, L-arginine and IGF-1 in the process of skeletal muscle regeneration through stimulation of myogenic satellite cells.

\section{Material and Methods}

Animals and muscle model of
degeneration

Fifty- five male rats with age of 6-8 weeks were used. The tibialis anterior (TA) muscle was chosen due to its planter flexor role and not involved in body weight bearing. Animals were kept 15 days for adaptation with water and balanced ration ad libitum. All handling and treatment protocols were approved by research community of Animal Health Research Institute

\section{Chemicals preparation}

Cardiotoxin (Sigma-Aldrich: Cat. NO. C9759); $10 \mathrm{uM}$ of cardiotoxin was dissolved in PBS and stored at $4{ }^{\circ} \mathrm{C}$.

L-arginine (Sigma-Aldrich; P code: A809A); was freshly prepared by dissolving in PBS.

Recombinant mouse insulin growth factor1 (IGF-I) (R\&D system: Cat. NO. 791-MG) was dissolved in normal serum, a liquated and preserved frozen.

Sera were collected from apparently health rats with age of 6-8 week. Serum content of IL- $1 \beta$ was estimated as $109.7 \mathrm{pG} / \mathrm{ml}$ and IL6 at level of $247.9 \mathrm{pG} / \mathrm{ml}$. Sera were a liquated and kept frozen.

M- cadherin primary anti-body (N-19, (Santa Cruz Biotch.: Cat. NO. SC-6740, goat polyclonal $\mathrm{IgG}$ ), and secondary mouse anti- goat IgG-HRP (SC-2354) was used according to manufacture kit's instruction.

\section{Protocol of muscle degeneration induction}

Fifty- five rats were used for muscle damage induction through cardiotoxin injection protocol (Lepper et al., 2009). Briefly; animals were anesthetized and hair of right and left hind limbs were shaved, Cardiotoxin was injected, intramuscularly, along the longitudinal axis of tibialis anterior muscle belly; at dose of $100 \mathrm{ul}$ (cardiotoxin) / muscle sing insulin syringe into the right legs. 


\section{Treatment Protocol}

One day post cardiotoxin injection 5 rats were anaesthetized and then scarified; another 5 rats (injected by Cardiotoxin only) were ethically sacrificed at the end of the experiment (14 day).

The other 45 rats were randomly divided into 3 groups, 15 animals /group as following; (a) Serum treated group (Cardiotoxin + serum), (b) L-arginine treated group (Cardiotoxin $+\mathrm{L}$-arginine) and (c) IGF-1treated group (Cardiotoxin + IGF-1).

The investigated treatment agents were used in the following doses: serum at dose of 10ul each /muscle, intra- muscular (i.m) (Haddad et al., 2005), L-arginine; at dose of $225 \mathrm{mg} / \mathrm{kg}$, intra- peritoneal (Anderson, 2000) and recombinant mouse IGF-I; at dose of $1.9 \mu \mathrm{g} /$ day, intra- muscular (Adams and McCue,1998).

Treatment agents were administrated 3 times /week for 2 weeks; treatment began one day post Cardiotoxin injection.

Animals in the established groups were scarified; 5 animals (from each treated group) at the days $3^{\text {rd }}, 7^{\text {th }}$ and $14^{\text {th }}$ of treatment, in each group. The tibialis anterior muscles of both treated and control groups were collected and fixed in formalin.

\section{Histopathological Investigations}

Formalin fixed paraffin embedded sections were processed routinely for $\mathrm{H} \& \mathrm{E}$ staining according to Suvarna et al., (2012). Further sections on positively charged coated slides were used for IHC technique using Mcadherin $\mathrm{Ab}$, as an indicator for regenerated myotubes. M-cadherin/IHC protocol was carried out according to manufacturer's kits instructions.

\section{Results}

\section{Pathological investigations}

Macroscopically; localized swollen and redness of tibialis anterior muscle, post cardiotoxin injection, was clear evidence.

Microscopically; the microscopic picture of degenerated muscles, at one day interval post cardiotoxin injection, showed hyalinized muscle bundles that appeared highly eosinophilic rounded bundles; there were inflammatory cell infiltrations (Fig. 1A) in addition to corrugated appearance in longitudinal section (Fig. 1B). At the $14^{\text {th }}$ day investigated muscles revealed small callipered size muscle bundles with marked interstitial edema (Fig. 1C). Longitudinal section revealed damaged muscle tissue that loss organized architecture (Fig. 1D).
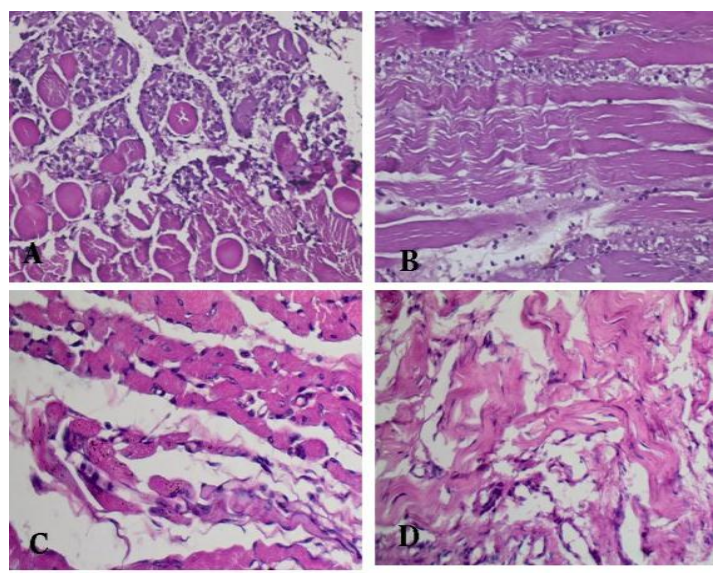

Fig. 1. One day post $\mathrm{Cr}$ injection.

Cross section reveals highly eosinophilic hyalinized degenerated muscle bundles; with inflammatory cell infiltrations (A). Longitudinal section reveals truncated muscle bundles which had wavy appearance (B). At the $14^{\text {th }}$ day post $\mathrm{Cr}$ injection; cross section reveals small callipered size muscle bundles with marked interstitial edema (C). Longitudinal section reveals damaged muscle bundles that loss organized architecture. H\&E X 200. 
At the $3^{\text {rd }}$ day; all treated groups revealed variable degrees of muscle regeneration. Cross sections of muscle in all treated groups; appeared atrophied, highly eosinophilic and separated by faint pink edematous fluid with inflammatory cell infiltrations; in addition to some characteristic features in each group; Serum treated group characterized by small sized muscle bundle diameters (Fig. 2A). Larginine treated group had, characteristic, high incidence of centrally localized myonuclei (Fig. 2B). IGF-1 treated group had marked interstitial edema with moderate inflammatory cell infiltrations (Fig. 2C).

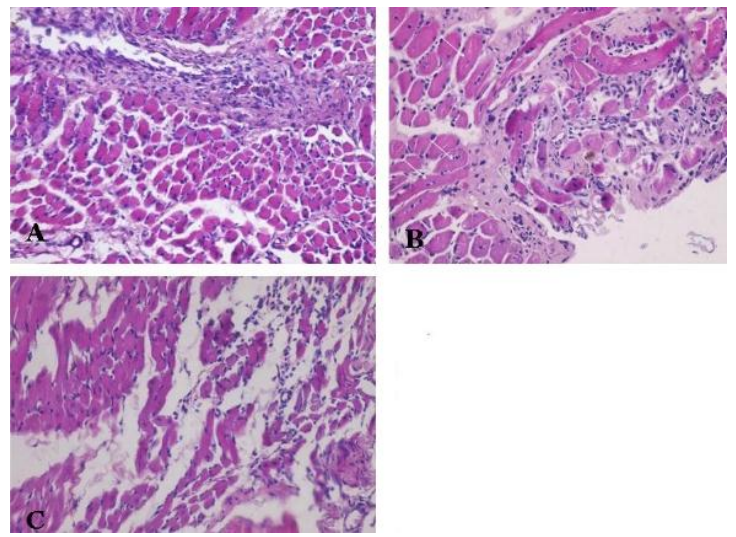

Fig. 2. Cross sections of treated groups at $3^{\text {rd }}$ days interval. Serum treated group, muscle bundles characterized by small diameter with highly eosinophilic appearance and inflammatory cell infiltrations (A). L-arginine group reveal high incidence of centrally localized myonuclei in muscle bundles associated with infiltration of inflammatory cells (B). IGF-1 treated group, there is marked interstitial edema with inflammatory cell infiltrations. The muscle bundles had small size (C). H\&E X 200.

Longitudinal sections of treated muscle bundles in different groups exhibited variable changes. Serum treated group; there was high incidence of fragmented muscle bundles (Fig. 3A). L-arginine treated group had truncated muscle bundles associated with moderate increase in the inter - bundles myonuclei (Fig. 3B). While IGF treated group revealed muscle bundles with small diameter and marked increase in the number of inter- bundles localized (vesicular) myonuclei (Fig. 3C).
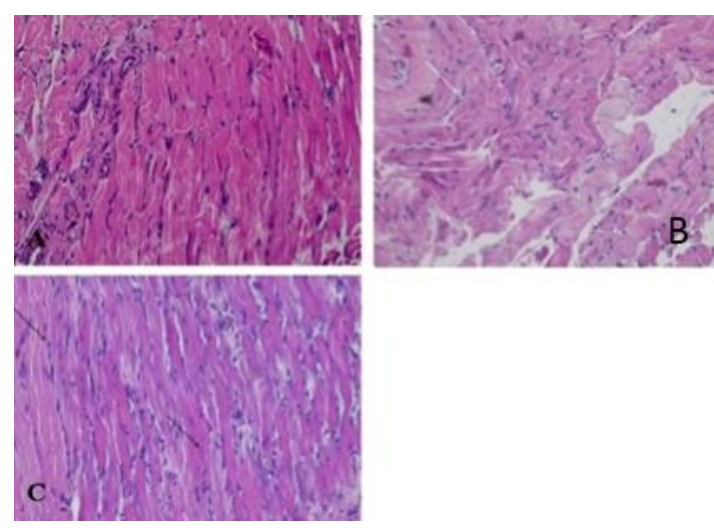

Fig. 3. Longitudinal sections of treated groups at the $3^{\text {rd }}$ days interval. Serum treated group, show fragmentation of muscle bundles with loss of striation (A). L-arginine group reveal truncated muscle bundles, with high number of inter- bundles myonuclei (B). IGF-treated group, there is high incidence of inter-bundles vesicular myonuclei (C). H\&E X 200.

At the $7^{\text {th }}$ day; evidence of regenerative process was exhibited in different treated groups at variable degree.

Cross sections: Serum treated group; the regenerative process gave high number of small callipered sized myofibers others appeared fragmented due to intra-bundles edema (Fig. 4A). L-arginine treated group revealed considerable number of regenerated fibers that had angular appearance and some exhibited eosinophilic cytoplasm (Fig. 4B). IGF-1 treated group revealed large sized myofibers with high incidence of regeneration in form of centrally localized myonuclei, other myofibers had small size with angular appearance (Fig. 4C). 


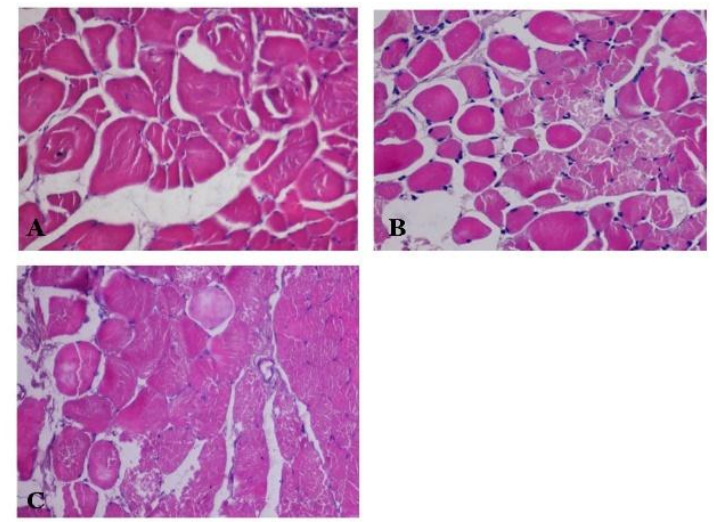

Fig. 4. Cross sections of treated groups at the $7^{\text {th }}$ days interval. Serum treated group; marked fragmentation of muscle bundles, most of them are angular with small diameter (A). L-arginine group, muscle bundles of both angular and circular appearance (B). IGF-1 treated group, less number of muscle bundles had angular or rounded appearance (C). H\&E X 400

Longitudinal sections: Serum treated group still revealing features of degeneration in form of increase number of contraction bands and truncated muscle bundles (Fig. 5A). L-arginine treated group; there were high incidence of peripherally localized myonuclei (Fig. 5B). IGF-1 treated group; considerable numbers of myofibers restore muscle striations, but some myofibers still showing features of degeneration (Fig. 5C).

At the $14^{\text {th }}$ day; most of treated groups exhibited variable stages of regeneration with different degrees of restoring normal criteria. Cross sections: Serum treated group; the regenerated myofibers showed marked variations in their diameter with angular appearance associated with marked edema (Fig. 6A). L-arginine treated group; muscle bundles composed of regenerated

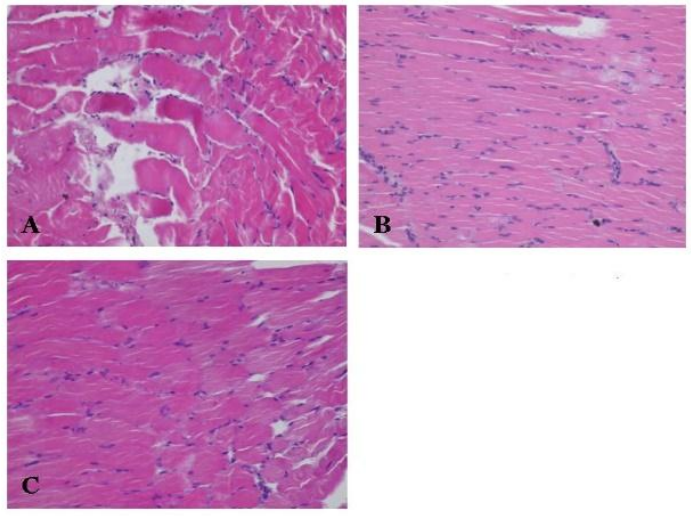

Fig. 5. Longitudinal sections of treated groups at the $7^{\text {th }}$ days interval. Serum treated group persistence of features of degeneration in form of increase number of contraction bands, truncated muscle bundles (A). L-arginine group reveal high number of peripherally localized myonuclei (B). IGF-1 treated group, most of muscle bundles restore muscle striations, but some still appeared degenerated (C). H\&E X 400.

small sized myofibers with angular appearance within a perimyosium (Fig. 6B). IGF-1 treated group; restoration of normal muscle architecture was clear with few number of centrally localized myonuclei while there was marked increase in the peripherally localized myonuclei (Fig. 6C).

Longitudinal section: Serum treated group; the muscle bundles revealed less degree of regeneration; appeared fragmented and wavy. Some fibers still had features of degeneration in the form of swollen highly eosinophilic cytoplasm with loss of striations (Fig. 7A). L-arginine treated group; some of the regenerated myofibers still exhibiting highly eosinophilic cytoplasm, with increase in the number of peripherally localized myonuclei. There were some areas had splitting bundles (Fig. 7B). IGF-1 treated group; the regenerated myofibers represented activated satellite 

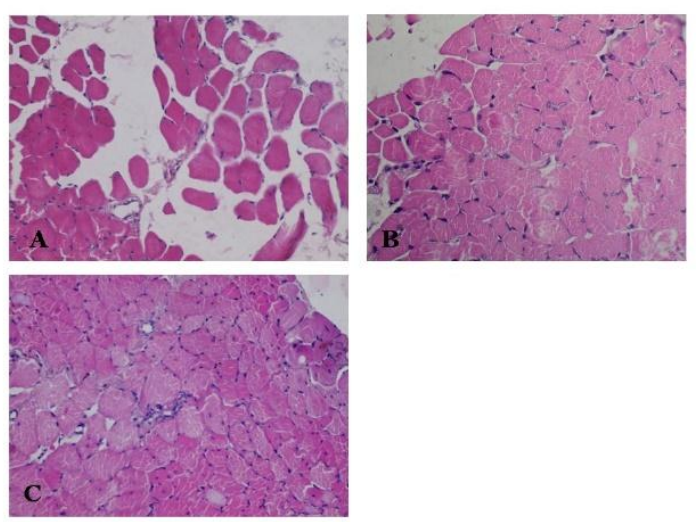

Fig. 6. Cross sections of treated groups at the $14^{\text {th }}$ days interval. Serum treated group, considerable number of muscle bundles had angular appearance (A). L-arginine group the regenerated angular muscle bundles enclosed within the perimyosium (B). IGF-treated group, there is high incidence of muscle bundles with peripherally localized and few with centrally localized myonuclei (C). H\&E X 400

cells that arranged in form of rows of internal myoblast nuclei. Some fine myofibers having splitting appearance (Fig. 7C).
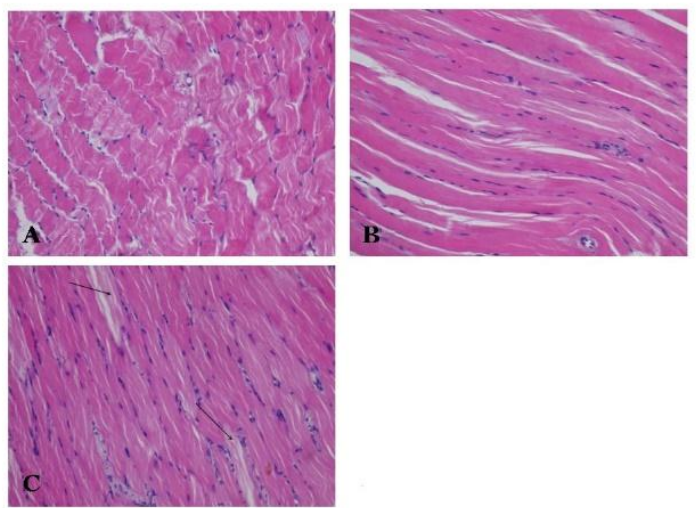

Fig. 7. Longitudinal sections of treated groups at the $14^{\text {th }}$ days interval. Serum treated group, the muscle bundles appeared fragmented and wavy (A). L-arginine treated group reveal moderate number of peripherally localized myonuclei with areas of splitting bundles (B). IGF-treated group, high number of peripherally localized vesicular myonuclei associated with few split muscle bundles (C). H\&E X 400.
IHC, M-cadherin was used to demonstrate the newly formed myotubes, serum - treated group indicated to incomplete fusion of newly formed split myotubules that characterized by small sized muscle bundles (Fig. 8A), in L-arginine treated group the newly developed myotubes incorporated into muscle bundles in organized pattern, but still split (Fig. 8B); while IGF-1treated group, the regenerated myotubules had organized appearance (Fig. 8C).

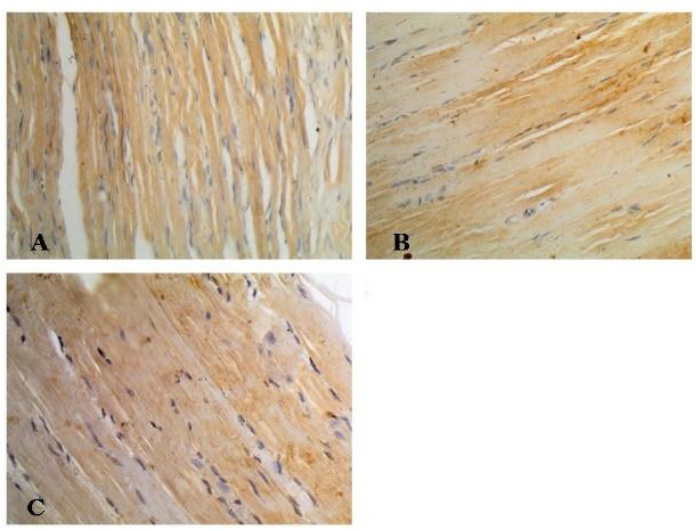

Fig. 8. Longitudinal sections of treated groups at 14 days interval. Serum treated group revealed considerable number of regenerated, but fragmented and rarefied muscle bundles (A). L-arginine group the regenerated muscle bundles appeared rarified (B). IGF-1 treated group, the regenerated muscle bundles had variable sizes and almost normal criteria, associated with interstitial edema (C).M-cad / IHCX 400.

\section{Discussion}

As there are a myriad of extrinsic and intrinsic factors control signaling pathways leading to satellite cell activation, proliferation and differentiation, so in this study we compare the myogenic regenerating capacity of physiological serum, L-arginine and IGF-1.

The time course was selected to capture the initial response including; inflammatory 
and degenerative events (1 day), the peak of inflammation and degeneration response (3 days), primarily structural and functional muscle recovery ( 7 days) and typical muscle reconstruction periods (14 days) so we could be able to cover all crucial stages of regenerative and reconstructive stages (Warren et al., 2007 and Przewoźniak et al., 2013).

In the present study, one day post cardiotoxin injection the degenerated muscle fibers exhibited manifestations of hyalinization and lyses; that is characteristic to myotoxin effect (Shi and Garry, 2006) in addition to intense inflammatory cell infiltrations. In serum treated group, IL-6 level was compatible to the local infused dose investigated by Haddad et al., (2005) and simulating the serum content in response to exercise (Benatti and Pedersen, 2014).

It has been proposed that IL-6 (Steensberg et al., 2001), IL-1 $\beta$ (Cannon et al., 1986) in addition to tumor necrosis factor- $\alpha$ (TNF- $\alpha$ ) (Febbraio and Pedersen, 2002) are produced by skeletal muscles, in response to strenuous and prolonged exercise, to maintain the metabolic homeostasis of lipids and proteins; and to stimulate myogenic satellite cells proliferation and thereby help in the regeneration of damaged myofibers and /or muscle hypertrophy.

Histopathological investigation of serum treated group indicated a low grade regenerative capacity. At the $14^{\text {th }}$ day of treatment; despite the angular shape of (regenerated) myofibers, treated muscles still showing features of damage in the form of short fragmented muscle bundles which composed of eosinophilic thin wavy myofibers; that represent unhealthy myofibers (Buono et al., 2012).

IL-6 as a known myogenic factor had 2 distinct effects; under some pathological conditions, IL-6 may lead to muscular atrophy (Tsujinaka et al., 1996) on the other side (at skeletal muscle tissue level) IL-6 may promote the proliferation of satellite cells and their incorporation as new myonuclei into existing fiber syncytia (Cantini et al., 1995). This effect depends on the level and sustainability of IL-6; Low levels of IL-6 can promote activation of satellite cells and myotube regeneration while systemic chronically elevated IL-6 lead to skeletal muscle wasting (Belizário et al., 2016). IL-6 activate Stat 3 signaling pathway that regulates satellite cell behavior, promoting myogenic lineage progression through regulatory effect on gene expression of myogenic differentiation 1 (Myod1) (Serrano et al., 2008 and Tierney et al., 2014).

Another item of the serum was IL-1 $\beta$. IL-1 $\beta$ (alone) had a stimulation effect on nuclear kappa- $\beta$ factor $(\mathrm{NF}-\kappa \beta)$ activity and thus increases the muscle cell proliferation through increase in the mitogenic activity of satellite cells (Otis et al., 2014). While systemic elevation of IL- $1 \beta$ had catabolic effect on skeletal muscle through its effect on IGF-1 pathway and hence decreasing in the skeletal muscle protein synthesis (Adams, 2002). The end evaluation of serum elements ability to regenerate damaged muscle, revealed defect in the regeneration process than the ability to stimulate satellite cells activation

Regarding to L-arginine treated group; the regenerated muscle bundles (at $14^{\text {th }}$ day) revealed small sized highly eosinophilic myofibers with angular appearance. This eosinophilia could be attributed to protein synthesis and expression of embryonic myosin heavy chain (MHC) that aimed in the regenerative process (Yin et al., 2013). The small sized myofibers could be warranted to migration of the proliferating satellite cells (Yin, et al., 2013) and their 
failure to fuse together with end clusters of small caliber myofibers within the same basal lamina (Charge et al., 2002). We also detected considerable number of peripherally localized vesicular myonuclei that refer to myofibers maturation due to activated satellite cells (Przewoźniak et al., 2013).

The effect of L-arginine could be attributed to its denotation of nitric oxide (NO). NO is a diffusible small molecule which can freely pass through cell membranes (Anderson, 2000). Production of NO is mediated by nitric oxide synthase (NOS) that produced from damaged or stretched muscle basal lamina, macrophages and fibroblasts (Bogdan, 2001). Nitric oxide activate matrix metalloproteins with release of hepatocyte growth factor (HGF) ending by activation of quiescent satellite cells (Tatsumi et al., 2006 and Yamada et al., 2006) with subsequent its migration and incorporation in the regeneration process (Collins-Hooper et al., 2012); in addition to its role in tissue remodeling through its inhibitory effect on transforming growth factor- $\beta$ (TGF- $\beta$ ) so inhibit fibrosis during muscle regeneration (Darmani et al., 2004) and hence improve tissue remolding (Yin et al., 2013), these facts were clear in the results of L-arginine treated group.

Thus, the synergistic effect between macrophages (as a producer of NOS) and Larginine (as a donor of NO) on the component of muscular tissue (inhibition of fibrosis) and secretion of growth factors that activate satellite cell in association with helping in tissue remodeling, that end in initiation of successes (but delayed) regenerative outcome as present in our study (not completed at the $14^{\text {th }}$ day).

IGF-1 is one of the most important anabolic factors involved in skeletal development and regeneration (Florini et al., 1996 and
Clemmons, 2009). IGF-1 is secreted by liver in 2 isoforms; mechano- growth factor (MGF) transcript and IGF-1transcript that incorporated in tissue maintenance through regulation of protein synthesis.

In post-natal stage; IGF-1is involved in the activation, proliferation, and differentiation of satellite cells (Hill and Goldspink, 2003 and Mourkioti and Rosenthal, 2005) to preserve skeletal mass maintenance so it had been implicated as a central regulator of muscle repair and modulation of muscle size. There is evidence that locally produced (autocrine/paracrine functioning) IGF-I may be important in skeletal muscle regeneration process as IGF-1 demonstrated an increased immunoreactivity in the cytoplasm of myoblasts and myotubes as well as in satellite cells during muscle regeneration (Barton et al., 2002).

The incidence of centrally located nuclei was highest in IGF-1 treated group; that indicate to regeneration of damaged myofibers (Buono et al., 2012), associated with increase in myonuclei migration at the bundles' periphery, that refer to further myofibers maturation; these observations supported by findings of Przewoźniak, et al., (2013). This migration process is mediated by M-cadherin, a cell adhesion molecule, that upregulated in activated satellite cells and help in its anchoring and/ or migration (Irintchev et al., 1994). While the longitudinal section, revealed localized areas of fibers splits; Schmalbruch (1976) attributed it to the newly formed myotubes that formed by satellite cells to replace damaged fibers (early step for regeneration) and displaced the surrounding endomysium; while Charge et al., (2002) considered it as a defect in the regenerative process, in which the differentiated satellite cell (s) attach to one end of the existing myofibers with incomplete fusion of the regenerating myoblasts into the same basal 
lamina (Bourke et al., 2009). Ligation of IGF-1 to it receptors initiate a cascade of both extracellular and intracellular signals (Barton et al., 2002) to stimulate the process of muscle hypertrophy and /or regeneration via a cascade of cellular signals including; induction of cell proliferation and increased translation with net end of enhanced protein synthesis machinery (Barton et al., 2002).

In the present study locally infused IGF-1 group revealed accelerated regenerating response, this anabolic effect agrees with findings of Adams and McCue (1998) who explained that potential effect by increasing MyoD expression and activating satellite cells. Furthermore, Pelosi et al., (2007) added that IGF-1 down regulate the proinflammatory cytokines, in injured muscles, so it helps in tissue remolding. So, we suggested that IFG-1 had a dual effect in the myogenic regeneration; through modulation of the inflammatory effect with down regulation of TGF- $\beta$, so inhibit scar formation (Barton et al., 2002), secondly through initiation of satellite cells activation, proliferation and differentiation (Musaro et al., 2001).

\section{Conclusion}

We could conclude that IGF-1 had an accelerating regenerative process (but incompletely successive), L-arginine had perfect but delayed myogenic regenerative capacity; while serum treated group lead to defected regenerative process. So, for healthy and functional regenerated muscle mass synchronized agents should be selected.

\section{References}

Adams GR (2002). Invited Review: Autocrine/paracrine IGF-1 and skeletal muscle adaptation. Journal of Applied Physiology, 93(3):11591167.

Adams GR, McCue SA (1998). Localized infusion of IGF-I results in skeletal muscle hypertrophy in rats. Journal of Applied Physiology, 84: 17161722.

Anderson JE (2000). A role for nitric oxide in muscle repair: nitric oxidemediated activation of muscle satellite cell. Molecular Biology of The Cell, 11 (5):1859-1874.

Barton E, Morris L, Musaro A, Rosenthal N, Sweeney H (2002). Musclespecific expression of insulin-like growth factor I counters muscle decline in mdx mice. Journal of Cell Biology, 57(1):137-48.

Belizário JE, Fontes-Oliveira CC, Borges JP, Kashiabara JA, Vannier E (2016). Skeletal muscle wasting and renewal: a pivotal role of myokine IL-6. Springerplus, 5:619.

Benatti FB, Pedersen BK (2014). Exercise as an anti-inflammatory therapy for rheumatic diseases-myokine regulation. Nature Reviews Rheumatology, 11(2):86-97.

Bogdan C (2001). Nitric oxide and the regulation of gene expression. Trends in Cell Biology, 11: 66-75.

Bourke VA, Watchman CJ, Reith JD, Jorgensen ML, Dieudonnè A, Bolch WE (2009). Spatial gradients of blood vessels and hematopoietic stem and progenitor cells within the marrow cavities of the human skeleton. Blood, 114 (19):40774080.

Buono R, Vantaggiato C, Pisa V, Azzoni E, Bassi MT, Brunelli S, Sciorati C, Clementi E (2012). Nitric oxide sustains long-term skeletal muscle regeneration by regulating fate of satellite cells via signaling pathways requiring Vangl2 and cyclic GMP. Stem Cells, 30(2):197-209. 
Cannon JG, Evans WJ, Hughes VA, Meredith CN, Dinarello CA (1986). Physiological mechanisms contributing to increased interleukin-1 secretion. Journal of Applied Physiology, 61(5):18691874

Cantini M, Massimino ML, Rappizzi E, Catani C, Dalla Libera L, Carraro U (1995). Human satellite cell proliferation in vitro is regulated by autocrine secretion of IL-6 stimulated by a soluble factor(s) released by activated monocytes. Biochemical and Biophysical Research Communications, 216(1):49-53

Chang NC, Rudnicki MA (2014). Satellite cells: the architects of skeletal muscle. Current Topics in Developmental Biology, 107:161181.

Charge SB, Brack AS, Hughes SM (2002). Aging-related satellite cell differentiation defect occurs prematurely after Ski-induced muscle hypertrophy. American Journal of Physiology Cell Physiology, 283: C1228-C1241.

Clemmons DR (2009). Role of IGF-I in skeletal muscle mass maintenance. Trends in Endocrinology \& Metabolism, 20: 349-356.

Collins-Hooper H, Woolley TE, Dyson L, Patel A, Potter P, Baker RE, Gaffney EA, Maini PK, Dash PR, Patel K (2012). Age-related changes in speed and mechanism of adult skeletal muscle stem cell migration. Stem Cells, 30: 1182-1195.

Darmani H, Crossan J, McLellan SD, Meek D, Adam C (2004). Expression of nitric oxide synthase and transforming growth factor-beta in crush-injured tendon and synovium.
Mediators of Inflammation, 13(56):299-305.

Febbraio MA, Pedersen BK (2002). Muscle-derived interleukin-6: mechanisms for activation and possible biological roles. FASEB J, 16(11):1335-1347.

Florini JR, Ewton DZ, Coolican SA (1996). Growth hormone and the insulinlike growth factor system in myogenesis. Endocrine Reviews, 17:481-517.

Haddad F, Zaldivar F, Cooper D.M, Adams GR (2005). IL-6-induced skeletal muscle atrophy. Journal of Applied Physiology, 98(3):911-917.

Hill M, Goldspink G (2003). Expression and splicing of the insulin-like growth factor gene in rodent muscle is associated with muscle satellite (stem) cell activation following local tissue damage. The Journal of Physiology, 549(2):409-418.

Irintchev A, Zeschnigk M, StarzinskiPowitz A, Wernig A (1994). Expression pattern of M-cadherin in normal, denervated, and regenerating mouse muscles. Developmental Dynamics, 199 (4):326-337.

Lepper C, Conway SJ, Fan CM (2009). Adult satellite cells and embryonic muscle progenitors have distinct genetic requirements. Nature, 30; 460 (7255):627-631.

Mourkioti F, Rosenthal N (2005). IGF-1, inflammation and stem cells: interactions during muscle regeneration. Trends in Immunology, 26: 535-542.

Musaro A, McCullagh K, Paul A, Houghton L, Dobrowolny G, Molinaro M, Barton ER, Sweeney HL, Rosenthal N (2001). Localized Igf-1 transgene expression sustains hypertrophy and regeneration in senescent skeletal 
muscle. Nature Genetics, 27: 195200.

Otis JS, Niccoli S, Hawdon N, Sarvas JL, Frye MA, Chicco AJ, Lees SJ (2014). Pro-inflammatory mediation of myoblast proliferation. PLoS One, 19; 9 (3):e92363.

Pal M, Febbraio MA, Whitham M (2014). From cytokine to myokine: the emerging role of interleukin-6 in metabolic regulation. Immunology and Cell Biology, 92 (4): 331-339.

Pedersen BK, Febbraio MA (2012). Muscles, exercise and obesity: skeletal muscle as a secretory organ. Nature Reviews Endocrinology, 8(8):457-465.

Pelosi L, Giacinti C, Nardis C, Borsellino G, Rizzuto E, Nicoletti C, Wannenes F, Battistini L, Rosenthal N, Molinaro M, Musaro A (2007). Local expression of IGF-1 accelerates muscle regeneration by rapidly modulating inflammatory cytokines and chemokines. FASEB J, 21: 1393-1402.

Przewoźniak M, Czaplicka I, Czerwińska AM, Markowska-Zagrajek A, Moraczewski J, Stremińska W, Jańczyk-Ilach K, Ciemerych MA, Brzoska E (2013). Adhesion Proteins - An Impact on Skeletal Myoblast Differentiation. PLoS One, 8(5): e61760.

Rigamonti E, Touvier T, Clementi E, Manfredi AA, Brunelli S, RovereQuerini P (2013). Requirement of inducible nitric oxide synthase for skeletal muscle regeneration after acute damage. The Journal of Immunology, 190(4):1767-1777.

Schmalbruch H (1976). The morphology of regeneration of skeletal muscles in the rat. Tissue Cell, 8(4): 673-692.

Serrano AL, Baeza-Raja B, Perdiguero E, Jardí M, Muñoz-Cánoves P (2008). Interleukin-6 is an essential regulator of satellite cell-mediated skeletal muscle hypertrophy, 7(1):33-44.

Shi X, Garry DJ (2006). Muscle stem cells in development, regeneration, and disease. Genes \& Development, 20: 1692-1708.

Steensberg A, Febbraio MA, Osada T, Schjerling P, van Hall G, Saltin B, Pedersen BK (2001). Interleukin-6 production in contracting human skeletal muscle is influenced by preexercise muscle glycogen content. The Journal of Physiology, 537(2): 633-639.

Suvarna KS, Layton Ch, Bancroft JD (2012). Bancroft's Theory and Practice of Histological Techniques: Expert Consult: Online and Print, 7e $7^{\text {th }}$ Edition. Hardcover ISBN: 9780702042263. Imprint: Churchill Livingstone.

Tatsumi R, Liu X, Pulido A, Morales M, Sakata T, Dial S, Hattori A, Ikeuchi Y Allen RE (2006). Satellite cell activation in stretched skeletal muscle and the role of nitric oxide and hepatocyte growth factor. American Journal of Physiology/Cell. Physiology, 290: C1487-C1494.

Tierney MT, Aydogdu T, Sala D, Malecova B, Gatto S, Puri PL, Latella L, Sacco A (2014). STAT3 signaling controls satellite cell expansion and skeletal muscle repair. Nature Medicine, 20(10):1182-1186.

Tsujinaka T, Fujita J, Ebisui C, Yano M, Kominami E, Suzuki K, Tanaka K, Katsume A, Ohsugi Y, Shiozaki H, Monden M (1996). Interleukin 6 receptor antibody inhibits muscle atrophy and modulates proteolytic systems in interleukin 6 transgenic mice. The Journal of Clinical Investigation, 97(1):244-249. 
Warren GL, Summan M, Gao X, Chapman R, Hulderman T, Simeonova PP (2007). Mechanisms of skeletal muscle injury and repair revealed by gene expression studies in mouse models. The Journal of Physiology, 582(2): 825-841.

Yamada M, Tatsumi R, Kikuiri T, Okamoto S, Nonoshita S. Mizunoya W, Ikeuchi Y, Shimokawa H,
Sunagawa K, Allen RE (2006).

Matrix metalloproteinases are involved in mechanical stretchinduced activation of skeletal muscle satellite cells. Muscle Nerve, 34: 313-319.

Yin H, Price F, Rudnicki MA (2013). Satellite Cells and the Muscle Stem Cell Niche. Physiological Reviews, 93(1):23-67. 